\title{
Hydraulic conductivity of peat in Western Siberia
}

\author{
Violetta Kramarenko ${ }^{1, *}$, Natalya Brakorenko ${ }^{1}$, and Viktor Molokov ${ }^{1}$ \\ ${ }^{1}$ National Research Tomsk Polytechnic University, 634050, Tomsk, Russia
}

\begin{abstract}
The paper aims at estimating hydraulic conductivity of peat. It is a complicated process since peat has some unique properties that are not typical for mineral soils. Other difficulties involve the lack of elaborated procedure for laboratory testing and data processing, high sensitivity of peat soils to external and internal factors; which leads to considerable fluctuation in peat hydraulic conductivity values. The specific properties of hydraulic conductivity in peat soils are proved by numerous experimental data. The article also provides the permeability values for the most typical peat species in Western Siberia. The obtained data allow forecasting peat soil response to the development of peatlands.
\end{abstract}

\section{Introduction}

Hydraulic properties of peats are one of the main factors to be taken into consideration while developing the vast peatlands in Western Siberia. This factor is even more important when the peat deposits are drained, or peat consolidation under constructions and facilities is examined. It is also significant while studying the processes of soil contamination and soil remediation. The research aims at measuring hydraulic conductivity of peat samples that represent the most characteristic and widespread species in Western Siberia. The basic objectives are as follows: to review the works that describe the procedures to determine organic soil permeability; to carry out laboratory tests to measure hydraulic conductivity of various peat species; and to find the links between physical properties and hydraulic conductivity of peats.

The results of research on peat permeability are provided in [1-9] for the European part of Russia and Belorussia, and in [10-11] for Western Siberia. Field and laboratory permeability tests in peat are described in international studies [12-16]. It should be noted that the number of detailed research on hydraulic conductivity of various peat species is insufficient, which makes the study relevant. Peats have a number of unique properties that cannot be attributed to mineral soils, which impedes their permeability estimation. Some researchers point out $\mathrm{pH}$ changes and gel formation during the laboratory tests $[1,2]$; some authors register swelling [3], pore clogging [4], changes in viscosity [5, or a combination of the factors mentioned herein above [6]. F.P. Vinokurov notes [3], "none of the factors that are supposed to impede

\footnotetext{
${ }^{*}$ Corresponding author: kramarenko-v-v@ mail.ru
} 
hydraulic conductivity in peats can be considered to be absolutely veracious and trusted, each of them being rather the result of subjective conclusions". Peat soils in Western Siberia are oligotrophic, there is a significant amount of weakly decomposed sphagnum moss. High wetting ability rate and gas emission that clogges the pores during experimental water saturation, limit the active porosity of peats. There occur anaerobic processes in the peat samples that are under long-term examination. It leads to occurrence of methane, methyl, and aldehyde compounds, which reduces the seepage water flow rate [1].

Permebility becomes of non-linear character in the domain of small values of hydraulic gradients, which becomes obvious due to noticeable flow reduction. V.M. Goldberg studied the same processes in clay soils [7]. According to his study, the impact of the seepage gradient on the clay permeability is conditioned by visco-elastic properties of the bound water, and by heterogeneous links between the water and solid surface of the clay particles. The visco-elastic properties are noticeable at the initial seepage gradient; the heterogeneity of the links makes itself evident in the fact, that more (and more) bound water is involved in motion as the seepage gradient increases. These two parameters - the initial seepage gradient and heterogeneous links - are mutually dependent. As the seepage gradient rises, a pore diameter increases, since more and more bound water starts moving. Due to the applied pressure difference, the bound water is "pushed out" and leaves the pore space. As the pressure difference rises, the effective porosity should increase as well, however, it is supposed to stay stable in the area of high heads [7]. As regards peat soils, high heads of the seepage liquid cause not only "pushing out" of the bound water, but also the increase in effective porosity by removing solid particles of peat and squeezing the pores. There are data [3] describing deformation and the seepage head being damped. The destructive value of the gradient ranges between 11 and 51.

Another particular characteristic of peat is the initial seepage gradient. The initial gradients have been studied for a long time [10], however, there are numerous approaches to the phenomenon. The initial gradient is arbitrary defined, water motion is not excluded though being almost unidentified. Experiments proved that the values of initial gradients of heads can reach 15 and more in highly compressed and dispersed peats [8]. According to A.F. Pechkurov [10], the compacting tension of $0.10 \mathrm{MPa}$ accounts for the increase in the initial gradient, with hydraulic conductivity of peat decreasing hundredfold; the compacting pressure of $0.3 \mathrm{MPa}$ reduces peat permeability to zero. Exponential dependence of hydraulic conductivity coefficient on dry density and porosity coefficient that changes under loads was experimentally proved by V.I. Kosov and E.T. Bazin [8].

\section{Research methods}

The most typical and rare species peat for Western Siberia were sampled at peat deposits: Tagan, Ikushkino, Karasevo, Ol'gino, Ryzhikovo, Svetloe, Temnoe, Chaginskoe,. Sogra, UstKandinskoe, Chaginskoe, Changarskoe, Plotnikovskoe, Obskoe, Matiangovskoe, Clukvennoe, Korotkino-2, Vasugan (section 5) and some unmarked wetlands on the oil and gas fields of Tomsk oblast and Khanty-Mansiysk Autonomous Okrug. The following characteristics were determined: density $(\rho)$, particle density $\left(\rho_{\mathrm{s}}\right)$, dry density $\left(\rho_{\mathrm{d}}\right)$, water content $(w)$, void ratio (e), ash content $\left(\mathrm{D}_{\mathrm{as}}\right)$, botanical composition and the degree of peat decomposition $\left(\mathrm{D}_{\mathrm{dp}}\right)$. The experiment was conducted by the procedure described in [17]. To identify hydraulic conductivity anisotropy ratio, $k_{f}$ was measured triply in two directions (vertical and horizontal) after preliminary water saturation. More than 600 tests on measurements hydraulic 
conductivity coefficient were carried out. Peat samples with undisturbed structure were placed in Litvinov's device to be subjected to seepage flow with bottom-up heads of 30 or 50 . Distilled water at a temperature of $19^{\circ} \mathrm{C}$ was used as seepage liquid. The procedure did not allow for swelling and air adsorption, as well as it gave the opportunity to examine the process of water flow rate without changing a cylinder filled with water. The conducted experiments proved that seepage water flow rate depends on pore clogging, that is why the hydraulic conductivity coefficients are calculated with respect to maximum water rate values. After 1-10 minutes, the volume of the seepage water was measured with graduated flask and $k_{f}$ values were calculated using formula 1 corrected for temperature.

$$
k_{f}=\frac{Q \times l}{s \times h \times t \times r}
$$

where $k_{f}$ - hydraulic conductivity coefficient (m/day), Q - collected volume of water per time $\mathrm{t}, \mathrm{l}$ - length of the samples, $\mathrm{s}$ - area of the sample, $\mathrm{h}$ - head difference, $\mathrm{r}$ - Hazen's temperature correction.

Table 1 provides average values of physical properties, median-dual hydraulic conductivity coefficient values of 24 peat species, minimal and maximum values, and anisotropy coefficients calculated as the ratio of hydraulic conductivity coefficient measured vertically $\left(k_{f v}\right)$ to the coefficient measured horizontally $\left(k_{f h}\right)$.

Table 1. Hydraulic conductivity of peat soils.

\begin{tabular}{|c|c|c|c|c|c|c|c|c|c|c|}
\hline \multirow[b]{2}{*}{$\begin{array}{c}\text { Peat species } \\
\text { (number of samples) }\end{array}$} & \multirow[b]{2}{*}{$\begin{array}{c}D_{\text {as }} \\
\%\end{array}$} & \multirow[b]{2}{*}{$\begin{array}{c}\mathrm{D}_{\mathrm{dp}} \\
\%\end{array}$} & \multirow[b]{2}{*}{$\mathrm{e}$} & \multicolumn{2}{|c|}{$\mathrm{k}_{\text {fmedian }}, \mathrm{m} /$ day } & \multirow[b]{2}{*}{$\mathrm{k}_{\mathrm{a}}$} & \multicolumn{2}{|c|}{$\mathrm{k}_{\mathrm{f} \text { min }}, \mathrm{m} / \mathrm{day}$} & \multicolumn{2}{|c|}{$\mathrm{k}_{\mathrm{f}_{\text {max }}, \mathrm{m} / \text { day }}$} \\
\hline & & & & $\begin{array}{c}\text { vertical } \\
\text { direction }\end{array}$ & $\begin{array}{c}\text { horizontal } \\
\text { direction }\end{array}$ & & $\begin{array}{c}\text { vertical } \\
\text { direction }\end{array}$ & $\begin{array}{c}\text { horizontal } \\
\text { direction }\end{array}$ & $\begin{array}{c}\text { vertical } \\
\text { direction }\end{array}$ & $\begin{array}{c}\text { horizontal } \\
\text { direction }\end{array}$ \\
\hline Shrub (8) & 3,2 & 15 & 15,0 & 6,53 & 4,85 & 1,3 & 6,24 & 1,43 & 6,81 & 7,17 \\
\hline Complex high-moor (18) & 2,8 & \begin{tabular}{|l|l|}
13 \\
\end{tabular} & 17,0 & 2,51 & 1,95 & 1,3 & 1,54 & 0,99 & 3,67 & 3,22 \\
\hline Wood-hypnum (36) & 4,2 & 20 & 13,0 & 2,22 & 2,07 & 1,1 & 1,36 & 0,84 & 2,44 & 4,02 \\
\hline Sphagnum obtusum (41) & 8,2 & 29 & 11,0 & 1,98 & 0,81 & 2,4 & 1,71 & 0,62 & 2,89 & 1,19 \\
\hline Reed peat (47) & 4,6 & 9 & 19,0 & 1,76 & 0,7 & 2,5 & 0,25 & 0,48 & 3,06 & 1,45 \\
\hline High-moor scheuch & 3,2 & 14 & 18,0 & 1,45 & 0,63 & 2,3 & 0,02 & 0,24 & 5,68 & 1,87 \\
\hline Sphagnum magellan & 10,0 & 29 & 12,0 & 1,43 & 1,53 & 0,9 & 0,24 & 0,25 & 4,98 & 3,96 \\
\hline Sphagnum angustifol & 9,4 & 30 & 11,0 & 1,42 & 0,27 & 5,3 & 0,25 & 0,04 & 5,98 & 2,19 \\
\hline Pine-eriophorum (52) & 6,1 & 23 & 12,0 & 1,36 & 0,65 & 2,1 & 1,31 & 0,45 & 1,44 & 1,68 \\
\hline High-moor pir & 3,4 & 6 & 17,0 & 1,29 & 1,69 & 0,8 & 0,41 & 0,29 & 2,48 & 3,89 \\
\hline Low-moc & 7,1 & 31 & 12,0 & 1,28 & 1,33 & 1,0 & 0,25 & 0,48 & 5,23 & 4,02 \\
\hline Low-moor se & 15,0 & 15 & 13,0 & 1,2 & 0,54 & 2,2 & 1,18 & 0,2 & 1,51 & 2,03 \\
\hline Grass (18) & 9,1 & 33 & 8,9 & 1,12 & 1,1 & 1,0 & 0,18 & 0,46 & 1,14 & 1,23 \\
\hline Sedge-hypnum & 8,5 & 30 & 8,6 & 1,07 & 0,84 & 1,3 & 0,23 & 0,19 & 4,81 & 1,73 \\
\hline Sphagnum & 1,6 & 28 & 15,0 & 0,96 & 2,16 & 0,4 & 0,06 & 0,18 & 5,08 & 4,05 \\
\hline Birch (9) & 10,0 & 40 & 9,9 & 0,84 & 0,85 & 1,0 & 0,25 & 0,29 & 2,73 & 3,22 \\
\hline Low-moor & 20,1 & 30 & 10,0 & 0,84 & 0,48 & 1,8 & 0,54 & 0,48 & 2,12 & 0,48 \\
\hline Low-mo & 3,2 & \begin{tabular}{|c|}
15 \\
\end{tabular} & 15,0 & 0,8 & 0,8 & 1,0 & 0,08 & 0,06 & 4,20 & 4,55 \\
\hline Wood & 2,8 & 40 & 15,0 & 0,7 & 0,46 & 1,5 & 0,09 & 0,001 & 3,85 & 2,47 \\
\hline Bog-d & 3,4 & 13 & 13,0 & 0,0 & 0,58 & 1,0 & 0,45 & 0,48 & 1,39 & 1,63 \\
\hline Eriopl & 6,7 & 30 & 7,0 & 0,16 & 0,24 & 0,7 & 0,02 & 0,02 & 2,47 & 2,03 \\
\hline High-1 & 2,9 & \begin{tabular}{|l|}
40 \\
\end{tabular} & 8,9 & 0,04 & 0,16 & 0,3 & 0,02 & 0,04 & 0,17 & 0,48 \\
\hline Grass & 3,3 & \begin{tabular}{|l|}
41 \\
\end{tabular} & 10,0 & 0,03 & 0,05 & 0,6 & 0,01 & 0,01 & 0,05 & 0,12 \\
\hline Pine-sphagnum (9) & 2,7 & 25 & 11,0 & 0,02 & 0,05 & 0,4 & 0,02 & 0,04 & 0,28 & 0,66 \\
\hline
\end{tabular}




\section{Results and discussions}

The laboratory tests proved that there are a number of specific features related to hydraulic conductivity in peat samples, the main being the change in seepage water flow rate. Some peat samples exhibit the increase in hydraulic conductivity at the beginning of the filtration, which may be explained by evacuating the gases that clogged the pores. The seepage water value reduces in the course of time in all the peat samples. The sphagnum peat with higher porosity values are more impacted by head gradient: as soon as the latter rises, the hydraulic conductivity rate increases. Some peat samples had initial gradients $\left(i_{0}\right)$ that grew up when the porosity coefficient decreased $\mathrm{i}_{0}=3.68-0.0998 \mathrm{e}$ (correlation coefficient $\mathrm{r}=-0.42$ ). The $\mathrm{i}_{0}$ values of sphagnum peat samples changed from 0.50 to 4.25 (40 measurements). The $k_{f}$ of the sphagnum peat soils that had been sampled at peat deposit "Ikushkino" $\left(\mathrm{e}_{0}=13.5-14.0, \mathrm{D}_{\mathrm{dp}}=\right.$ $20 \%)$ was measured after the samples being under the load $\left(\mathrm{P}_{\mathrm{i}}\right)$ of 0.02 and $0.06 \mathrm{MPa}$. These calculations proved that peat consolidation under the load significantly reduces water conductivity of the peat samples and is characterized by the exponential equation of the following specie: $\mathrm{k}_{\mathrm{f}}=0.136 \mathrm{e}^{-116,8 \mathrm{Pi}}(\mathrm{r}=-0.90)$.

The experiments proved that vertical hydraulic conductivity coefficients change from 0.012 to $6.81 \mathrm{~m} /$ day, horizontal hydraulic conductivity coefficients change from 0.007 up to $7.17 \mathrm{~m} /$ day and are distributed in accordance with the lognormal law. Sphagnum moss peats with high porosity exhibit more obvious dependence of $k_{f}$ on head gradient. When comparing peat species of the same porosity, it is noted that water conductivity of woody peat is notably higher than that of moos peat. The hydraulic conductivity coefficient of the moss peats is much more dependent on the increase in porosity coefficient if compared with the woody peat samples. There is no such relation between hydraulic conductivity and porosity in the grass peat samples, because the values for hydraulic conductivity and porosity are in a narrow range.

Shrub, fuscum, complex and wood-hypnum peats have high median-dual values for hydraulic conductivity (maximum values are highlighted in darker color in table). Pinesphagnum, eriophorum-sphagnum, eriophorum and grass-sphagnum peat have the lowest hydraulic conductivity. Shrub, fuscum, wood-hypnum, complex, pine and magellanicum species have the highest coefficient of permeability $k_{f h}$ in horizontal direction. Shrub, complex, wood-hypnum, obtusum, reed, scheuchzeria peats have the highest $k_{f h}$ for vertical direction. Moss peats - angustifolium and obtusum, grass peats - reed and scheuchzeria peats, as well as woody-grass - low-moor sedge-sphagnum peat species have the highest anisotropic coefficients. Vertical maximum conductivity $\left(\mathrm{k}_{\mathrm{fvmax}}\right)$ predominates in shrub, angustifolium, scheuchzeria, wood-sedge, fuscum, magellanicum, sedge-hypnum, low-moor sedge, woodsphagnum, and complex peats. Horizontal conductivity $\left(\mathrm{k}_{\mathrm{fhmax}}\right)$ predominates in shrub, sedge, fuscum, wood-hypnum, wood-sedge, magellanicum, complex and birch peat species.

\section{Conclusion}

Hydraulic conductivity of the peats with normal ash content depends on porosity and botanical content. The shrub and moos peats soils with high porosity have the highest coefficients of hydraulic conductivity. Though having the same porosity, the woody peats are more permeable, the moss peats are less permeable due to their hydrophilic nature. There is anisotropy of hydraulic conductivity in peat soils. The obtained results can be used while developing drainage of peat deposits or forecasting peat response to construction loads. 


\section{References}

1. N.F. Bondarenko, N.P. Kovalenko, Hydraulic properties of peatlands, 160 (1979)

2. N.F. Bondarenko, N.P. Kovalenko, Construction on peatlands: The first conference proceedin, 12, 188 (1972)

3. F.P. Vinokurov, A.E., Teterkin, M.A. Piterman, Construction properties of peat soils, $283(1962)$

4. K.E. Ivanov, Water exchange in bog lands, 280 (1975)

5. P.A. Drozd, Farm roads on moors, 167 (1966)

6. P.A. Konovalov. Foundation construction on peat soils, 160 (1980)

7. V.M. Gol'dberg, N.P. Skvorcov, Permeability and hydraulic conductivity in clay soils, 160 ( Moscow, 1986)

8. I.I. Lishtvan, E.T. Bazin, V.I. Kosov, Science and mechanics, 102 (Nauka i tehnika, Minsk, 1989)

9. A.F. Pechkurov, Stability of river and canal bed, 412 (Minsk, 1964)

10. P.E. Loginov, P.I. Horoshev, Peat resources of Western Siberian plane, 148 ( Moscow, 1972)

11. A.I. Sergeev, Methods for geological studying of peat lands, 135 (Science, Moscow, 1974)

12. C. McCarter, S.J. Ketcheson, T.K. Weber, D. Whittington, P.N., Scarlett, J.S. Price, Soil Sci. Soc. Am., 81, 747 (2017)

13. D.H. Boelter, Soil Science, 100, 227 (1965)

14. E.Rosa, M. Larocque, Hydrological Processes, 22, 12 (southern Quebec, Canada, 2007)

15. S.C. Iden, W Durner, Water Resour, 50, 4 (2014)

16. T.K. Weber, S. C. Iden, W. Durner, Hydrol. Earth Syst. Sci., 21, 6185 (2017)

17. V.N. Kolesina, Methods to determine hydraulic and mechanic characteristics of peat deposits for development draining nets: Best practices, 40 (KPI, 1983) 